\title{
Motivational Factors for the Adoption of ISO 9001 Standards in Eastern Europe: The Case of Bulgaria
}

\author{
Svetoslav Georgiev ${ }^{1}$, Emil Georgiev ${ }^{2}$ \\ ${ }^{1}$ Graduate School of Economics and Management, Tohoku University (Japan) \\ ${ }^{2}$ Department of Sociology, Sofia University "St. KlimentOhridski" (Bulgaria) \\ svetoslavggeorgiev@yahoo.com,emo.georgiev@,hotmail.com
}

Received: December 2014

Accepted: June 2015

\section{Abstract:}

Purpose: This study analyzes the motivational factors for ISO 9001 certification in Bulgaria from the internal/ external motivations perspective, or the so-called dual model.

Design/methodology/approach: This study is based on a mixed method research approach, which employed two interviews with experts in the field of quality management at the exploratory stage, and a survey involving 127 companies at the descriptive stage.

Findings: This study claims that enbanced company image and competitiveness - an external motivation - is the leading motivational factor for ISO 9001 certification in Bulgaria. At the same time, our primary investigation reveals that Bulgarian firms are not predominantly externally driven, for internal motivations including process improvement and product quality improvement seem to be an important driver for ISO 9001 certification. Last but not least, this research asserts that enhanced company image and competitiveness has a stronger impact on the motivations for ISO 9001 certification than customer and supplier pressure, which is in line with previous research works on developing economy economies such as Bulgaria. Finally, our study indicates a moderate, yet positive correlation between motivations for and benefits of ISO 9001 certification. 
Social implications: This research work casts some light on the evolution of quality management in Bulgaria since the end of communism, which can serve as an important foundation for the better understanding of quality management in former communist economies in general and Eastern European states in particular.

Originality/value: Derived from the acute gap between ISO studies in Western and former communist economies, this research work presents one of the first official, international studies in the field of ISO certification in Bulgaria, and more precisely, a paper describing the motives for ISO 9001 certification among Bulgarian businesses.

Keywords: quality standards, ISO 9000 series, certification, motivational factors, benefits, quality management, Bulgaria

\section{Introduction}

Since 1987, when the ISO 9000 QMS was initiated by the International Organization for Standardization (ISO) as part of the objective to standardise quality systems, the ISO 9000 family of standards has undergone major changes. Yet, regardless of these changes, studies on the motivational factors for obtaining ISO certification have remained in the limelight of research works in the field of quality management. Various perspectives of the motivations for ISO 9001 adoption have been considered throughout the years; yet, the bulk of the research works including those of Rayner and Porter (1991), Ebrahimpour, Withers and Hikmet (1997), Gustafsson, Klefsjo, Berggren and Granfors-Wellemets (2001), Torre, Adenso-Diaz and Gonzaléz (2001); Llopis and Tarí (2003), Neumayer and Perkins (2005), Heras-Saizarbitoria, Arana and San Miguel (2010), and others alike have considered these factors from a dual perspective that categorises them into internal (i.e. desire for improved productivity and profitability, decrease in cost) and external (i.e. pressure from clients or suppliers, enhanced company image) ones.

Studies from Singapore (ISO 9000 Survey, 1996), Australia (Jones, Arndt \& Kustin, 1997; Prajogo \& Sohal, 2006), Hong Kong (Leung, Lee \& Chan, 1999), Spain (Casadesús, Giménez \& Heras, 2001), Germany (Beck \& Walgenbach, 2003), Saudi Arabia (Kadasah, 2012), the U.K. (McCrosson, Cano, O'Neil \& Kobi, 2013), etc. claim that the external factors are superior to the internal ones. Nevertheless, the afore-mentioned economies have a number of common aspects, and more precisely these are market economies, which were never part of the Soviet Union and the Eastern Block (*the only exception is Germany - before the unification, Eastern Germany was under communist rule). On the other hand, in former centrally-planned economies such as Bulgaria, which had to undergo a transition from centrally-planned to market economy, similar studies have been extremely limited in number. 
Based on our extensive review of literature, the only relevant, internationally recognised work from Central and Eastern Europe (CEE) is a 2004-study conducted in Lithuania by Ruzevicius et al., whereas the remaining research projects in the region have addressed ISO certification from a different point of view from the one we have studied here. For example, in Serbia and Montenegro, one study looked at the difficulties of ISO implementation (Diaye, Jovanovic, Krivokapic, Pekovic \& Vujovic, 2008); in Slovenia, a study discussed the impact of ISO 9001 certification process on local companies (Pivka \& Ursic, 2002); and so on. Thus, overall, the main reasons for ISO 9001 adoption in Eastern Europe and the former Eastern Bloc states are relatively unknown, which is also due to the limited research works in the field of quality management in the CEE region.

In the case of Bulgaria, the lack of understanding of the quality movement and quality evolution is even more prevalent. Few local researchers have tried to address quality management systems such as ISO 9001 in the context of Bulgaria, yet due to the extremely limited sample size (between 15 and 20 companies), the value of their studies is extremely finite. Therefore, as the gap between ISO studies in Western and former communist economies is particularly acute, the aim of this paper is to provide detailed analysis of the main motivations for the adoption of ISO 9001 among Bulgarian firms from the internal/external motivations perspective, and to outline the possible outcomes of their adoption, thereby contributing to the understanding of the quality movement in former communist states.

This paper proceeds with a comprehensive literature review on the motivations for adoption of ISO standards in general, as well as in Eastern Europe and Bulgaria in particular. From there, the research methodology including the sampling and data collection techniques are described. Analysis of the gathered data and related discussion are presented next. This paper rounds off with a summary and suggestions for further research.

\section{Literature Review}

\subsection{Motivations for Adoption of ISO Standards}

Since the introduction of the ISO 9000 series in 1987, a great number of research papers on the topic "motivational factors for obtaining of ISO certification" have been published, yet the predominant research approach has looked at these factors from the so-called dual point of view, or in other words from the internal/external motivations perspective (for more information, please refer to Table 1 ). Based on this research approach, the internal factors include desire for improved productivity and profitability, decrease in cost, improved quality, etc., and the external ones include pressure from clients or suppliers, enhanced company image, and so on (Rayner and Porter, 1991; Ebrahimpour et al., 1997; Neumayer \& Perkins, 2005; Sampaio, Saraiva \& Guimaraes Rodrigues, 2010; etc.). 
Overall, the ISO 9000 family of standards has become a main prerequisite for entering the global market (Withers \& Ebrahimpour, 2000; Heras-Saizarbitoria et al., 2010), hence some of the previous research works on the reasons for obtaining ISO certification claim that the external factors are superior to the internal ones (Rayner \& Porter, 1991; Ebrahimpour et al., 1997; Anderson, Daly \& Johnson, 1999; Withers \& Ebrahimpour, 2000; Prajogo \& Sohal, 2006; Kadasah, 2012; McCrosson et al., 2013). The case of Japan provides strong evidence to the afore-mentioned statement: in the 90s, ISO 9001 certification became a requirement for exports to Europe. Hence, Japan was forced to obtain ISO certification in order to maintain and continue the expansion of its market share abroad (Pecht \& Boulton, 1995; Heras-Saizarbitoria et al., 2010).

Certainly, there are also those (Abraham, Crawford, Carter \& Mazotta, 2000; Casadesús \& Jiménez, 2000; Gupta, 2000; Sun, 2000; etc.) who argue that the adoption of standards such as the ISO 9000 series is internally-driven. In this case, as supported by Heras-Saizarbitoria et al. (2010), the adoption would most often depend on the company's specific organizational resources. For example, in the case of companies which aim for TQM implementation, ISO 9001 certification is a good starting ground for cost reduction and quality improvement (Martínez-Lorente \& Martínez-Costa, 2004). As Sun (2000) asserts, ISO 9001 certification can be beneficial if it is seen as a way towards TQM. Nevertheless, for ISO implementation requires a substantial financial resource, which can vary from as little as 10,000 USD to as much as 300,000 SD (Withers \& Ebrahimpour, 2000) and because the improvements yielded by such certification are debatable (Casadesús \& Karapetrovic, 2005), the so-called external motivations are somewhat overwhelming, it seems - see Table 1 below.

\begin{tabular}{|c|c|c|c|c|c|}
\hline \multicolumn{4}{|c|}{ Study } & \multicolumn{2}{|c|}{ Main Motivations } \\
\hline Year & Country & Sample & Author(s) & Internal & External \\
\hline 1995 & U.K. & 682 & Taylor & Quality improvement & Customer Pressure \\
\hline 1996 & Singapore & 363 & ISO 9000 Survey & - & Customer Pressure \\
\hline 1997 & EU & 500 & $\begin{array}{l}\text { Hardjono, Ten Have \& } \\
\text { Ten Have }\end{array}$ & - & Customer Pressure \\
\hline 1997 & Australia & 272 & Jones et al. & - & Customer Pressure \\
\hline 1999 & Hong Kong & 500 & Leung et al. & - & Customer Pressure \\
\hline 1999 & Greece & 111 & Lipovatz, Stenos \& Vaka & - & Customer Pressure \\
\hline 2001 & Spain & 749 & $\begin{array}{l}\text { Escanciano, Fernández } \\
\text { \& Vázquez }\end{array}$ & Improve efficiency & - \\
\hline 2001 & Spain & 502 & Casadesús et al. & - & Customer Pressure \\
\hline 2001 & Holland & 192 & $\begin{array}{l}\text { Singels, Ruël \& Van De } \\
\text { Water }\end{array}$ & Improve competitiveness & - \\
\hline 2002 & U.K & 1,066 & Boulter \& Bendell & Improve efficiency & External image \\
\hline 2003 & Spain & 106 & Llopis \& Tarí & Improve efficiency & External image \\
\hline 2003 & Egypt & 83 & Salaheldin & Improve efficiency & Customer Pressure \\
\hline 2003 & Far East & 2,951 & Pan & Improve efficiency & External image \\
\hline 2003 & Germany & 3,950 & Beck \& Walgenbach & - & Customer Pressure \\
\hline
\end{tabular}




\begin{tabular}{|c|c|c|c|c|c|}
\hline \multicolumn{4}{|c|}{ Study } & \multicolumn{2}{|c|}{ Main Motivations } \\
\hline Year & Country & Sample & Author(s) & Internal & External \\
\hline 2004 & Spain & 442 & $\begin{array}{l}\text { Martínez-Lorente \& } \\
\text { Martínez-Costa }\end{array}$ & Improve efficiency & - \\
\hline 2004 & Lithuania & 31 & $\begin{array}{l}\text { Ruzevicius, Adomaitiene } \\
\text { \& Sirvidaite }\end{array}$ & $\begin{array}{l}\text { Improving product/service } \\
\text { quality }\end{array}$ & $\begin{array}{l}\text { Improve the image and } \\
\text { prestige of the company }\end{array}$ \\
\hline 2006 & Australia & 1,300 & Prajogo \& Sohal & - & $\begin{array}{l}\text { Corporate image and } \\
\text { Customer pressure }\end{array}$ \\
\hline 2007 & $\begin{array}{l}\text { United Arab } \\
\text { Emirates }\end{array}$ & 900 & Zaramdini & $\begin{array}{l}\text { Improving processes, } \\
\text { procedures and } \\
\text { product/service quality }\end{array}$ & - \\
\hline 2008 & Egypt & 38 & Magd \& Curry & $\begin{array}{l}\text { Improving product/service } \\
\text { quality }\end{array}$ & $\begin{array}{l}\text { Pressure from } \\
\text { competitors }\end{array}$ \\
\hline 2008 & Greece & 69 & Kostagiolas \& Kitsiou & $\begin{array}{l}\text { Improvement of internal } \\
\text { operations }\end{array}$ & - \\
\hline 2008 & Spain & 713 & $\begin{array}{l}\text { Martínez-Costa, } \\
\text { Martínez-Lorente \& Choi }\end{array}$ & $\begin{array}{l}\text { Improving processes, } \\
\text { procedures and } \\
\text { product/service quality }\end{array}$ & Customer Pressure \\
\hline 2009 & Brazil & 45 & $\begin{array}{l}\text { Almeida, Caten \& } \\
\text { Gutterres }\end{array}$ & $\begin{array}{l}\text { Improving processes and } \\
\text { product quality }\end{array}$ & Improve competitiveness \\
\hline 2010 & Italy & 366 & $\begin{array}{l}\text { Cagnazzo, Taticchi \& } \\
\text { Fuiano }\end{array}$ & $\begin{array}{l}\text { Improving processes and } \\
\text { internal operations } \\
\text { efficiency }\end{array}$ & Corporate image \\
\hline 2012 & Saudi Arabia & 129 & Kadasah & - & Corporate image \\
\hline 2012 & Jordan & 130 & Al-Refaie, Ghnaimat \& Li & Business performance & Customer satisfaction \\
\hline 2013 & Kuwait & 98 & $\begin{array}{l}\text { Alolayan, Hashmi, Yilbas } \\
\text { \& Hamdy }\end{array}$ & Improve efficiency & External image \\
\hline 2013 & South Africa & 110 & Dongmo \& Onojaefe & - & $\begin{array}{l}\text { Customer satisfaction } \\
\text { and competitiveness }\end{array}$ \\
\hline 2013 & U.K & 111 & McCrosson et al. & - & Customer Pressure \\
\hline 2013 & Portugal & 427 & Santos \& Millán & $\begin{array}{l}\text { Improving product/service } \\
\text { quality }\end{array}$ & Corporate image \\
\hline 2014 & Sri Lanka & 200 & $\begin{array}{l}\text { Thilakarathne \& } \\
\text { Chithrangani }\end{array}$ & $\begin{array}{l}\text { Improving product/service } \\
\text { quality }\end{array}$ & Customer Pressure \\
\hline 2014 & Portugal & 426 & Santos, Costa \& Leal & $\begin{array}{l}\text { Improving product/service } \\
\text { quality }\end{array}$ & Corporate image \\
\hline
\end{tabular}

Table 1. Motivations for adoption of ISO 9000 family of standards - Review of Literature

(*empirical studies only)

\subsection{Motivations for Adoption of ISO Standards in Eastern Europe}

Few, not to say extremely limited, are the research works on former communist economies such as Bulgaria. Based on our review of literature (refer to Table 1), we could identify only one study on the motivations for adoption of ISO standards that was conducted in a former Eastern Bloc state; in this case, Lithuania. In the study, Ruzevicius et al. (2004) conclude that the motivational factors for ISO certification are both internal or more precisely being product quality improvement, and external, being enhanced company image. Nevertheless, the aforementioned study was conducted over ten years ago. Since then, as noted in the "Introduction" part, a number of ISO related works in Eastern Europe were initiated (Diaye et al., 2008; Abramuszkinova \& Kuřitkova, 2013; Žeželj, 2013), yet their research objectives were rather 
different, with the closest one to our topic of interest being "Typological Models of Motives and Effects of Adoption of ISO 9000 Series Standards", which was conducted in Lithuania in 2013 (Vilkas \& Vaitkevicius, 2013). Nevertheless, based on our review of literature and personal observations, a number of important claims can be made.

Quality awareness in Central and Eastern Europe and especially in the Eastern CEE states (i.e. Bulgaria and Romania) seems to be relatively low. For example, Matei and Lazar (2011) claim that in the case of public administration, quality management emerged only after year 2000. Further, as Otsuki (2011) notes, meeting international standards creates a rather favourable company image among clients and this is especially valid in the case of developing economies such as those in the CEE region. In line with this statement, it can be affirmed that former communist states such as Bulgaria are currently looking up to the industrial economies of the West in the pursuit of economic growth. This, however, is not surprising, for these states suffer from the image of low quality manufactures - an image that was established during the communist era and that was the mere result of Soviet-style management or Management Sovieticus, which almost always emphasized on the importance of quantity at the expense of quality (Lee, Luthans \& Hodgetts, 1992; Luihto, 1999). Hence, in the attempt to copy their Western counterparts, it is rather possible that companies in the former communist states are visualizing the adoption of ISO 9001 and other similar standards as successful business practices (Otsuki, 2011).

\subsection{Motivations for Adoption of ISO Standards in Bulgaria}

Our review of literature depicts no internationally recognised studies on the 'motivations for adoption of ISO standards' in Bulgaria. Not only that, but overall we claim that in the case of Bulgaria, there are no significant studies in the field of quality management in general and ISO standards in particular. One reason for this might be the relatively small size (appr. 111,000 sq. km) and population (7,245,677 - 2013 estimates, National Statistical Institute) of Bulgaria, and also the fact that since the collapse of communism, among the former communist states, Russia has been in the limelight of academic research works. Nevertheless, based on the limited information about the quality movement in Bulgaria, hereby we will assert a number of findings based on few local studies.

Empirical research conducted by Chankova (2006) with a limited sample of 15 Bulgarian companies operating in the logistic sector shows that their motivation for ISO 9001 certification is related to an effort towards management processes improvement. Furthermore, another study by Otzetova and Enimanev (2012), which analyses the adoption of management standards in Bulgarian courier companies, claims that certified companies are more competitive on the European market than those who do not possess a valid certificate. Finally, Striptzov (2012) asserts that after the accession of Bulgaria to the EU, ISO 9001 has become a 
major factor for competitiveness not only in the case of export goods, but also in the case of those intended for the Bulgarian market.

Based on the afore-mentioned statements as well as considering the fact that Bulgaria was one of the late adopters of ISO certification (according to the International Organization for Standardization, ISO 9001 certification in Bulgaria kicked off in 1997) compared to Western European states such as Italy and Spain for example, we believe that Bulgaria and its local businesses most probably followed a behaviour modelled by acquiring a legitimacy in an environment of uncertainty (Braun, 2005), or in other words certification driven by merely external factors. This statement is also supported by our correspondence with ISO 9001 auditors, representatives of local organizations promoting standardization, and so on. In fact, the predominant, yet unofficial opinion about motivations for ISO certification that lingers in Bulgaria is one that relates to company image (if you are ISO 9001 certified, then customers will perceive your products of better quality than those produced by firms without ISO 9001 certification) and access to government biddings (*in the last couple of years most government biddings in Bulgaria are limited to firms with ISO 9001 and other standards including ISO 14001:2004, ISO 27001:2013). Hence, our main hypotheses are as follows:

H1: The reasons for obtaining ISO 9001 certification in the case of Bulgarian firms are predominantly external.

H2: In the Bulgarian case, enhanced company image and competitiveness are stronger drivers of ISO 9001 certification than customer and supplier pressures/requirements.

\subsection{Relationship Between ISO 9001 Motivations and Benefits}

Besides the above listed two hypotheses, in order to enrich the understanding about ISO certification in Eastern Europe, we will also test one more hypothesis based on the motivations for ISO 9001 certification (internal/external) and their impact on company performance. A number of studies have addressed the correlation between motivations and benefits of implementation of ISO 9000 series. To name a few: Brown, Van der Wiele and Loughton (1998), Poksinska, Dahlgaard and Antoni (2002), Gotzamani and Tsiotras (2002), Llopis and Tari (2003), Williams, (2004), Castka, Balzarova and Kenny (2006), Jang and Lin (2008), Poksinska (2010), Santos and Millán (2013), Dongmo and Onojaefe (2013), etc. Moreover, like the motivations (internal/external), the ISO 9001 certification benefits can be classified into internal and external (Buttle, 1997; Brown et al., 1998; Ragothaman \& Korte, 1999; Liebesman, 2002; Corbett, Luca \& Pan, 2003; Bhuiyan \& Alam, 2004; Van der Wiele, Iwaarden, Williams \& Dale, 2005; Sampaio et al., 2010; etc.). 
For example Brown et al. (1998) argue that companies seeking certification driven by internal reasons have a more positive perception about achieved improvements. In other words, they assert that managers, who see certification as an opportunity to improve internal processes and systems, rather than simply wanting to get a certificate on the wall, would usually perceive broader positive results from ISO 9001 certification. Furthermore, Gotzamani and Tsiotras (2002) state that companies seeking ISO 9001 certification mainly based on external motivations would achieve mostly external benefits, while those who seek certification based on quality improvement would report benefits mainly in terms of internal operations improvement (Poksinska et al. 2002; Williams, 2004). Llopis and Tarí (2003) suggest that companies, which are more concerned about internal reasons are those that (1) obtain higher profits derived from the implementation of quality systems; (2) reach a greater practical implementation of quality management principles; and (3) are most likely to progress towards total quality management (TQM). In fact, Arauz and Suzuki (2004), in a study of 292 ISO 9000 certified companies in Japan, showed that internal motivation was the critical factor in terms of cost and quality performance. Overall, the common theory based on empirical evidence is that firms, which have implemented the ISO 9001 standard driven by internal motivations such as process improvement or product quality improvement, most often report positive improvements in this context in comparison with companies that have adopted the same standard driven by external factors such as enhanced company image and supplier pressure. In other words, the firms driven by external factors report external benefits (i.e. improved relationship with clients and suppliers) or no benefits at all (Heras-Saizarbitoria, Casadesús \& Ochao, 2001; Gotzamani \& Tsiotras, 2002; Llopis and Tarí, 2003; Magd \& Curry, 2003; Arauz \& Suzuki, 2004; Ruzevicius et al., 2004; Mersha, 2007; Zaramdini, 2007; Martínez-Costa et al., 2008; Sampaio, Saraiva \& Guimaraes Rodrigues, 2009, Kaziliūnas, 2010; Kawthar \& Vinesh, 2011). For the bulk of these studies comes from capitalist economies including New Zealand, Spain, Portugal, Taiwan, etc., we are interested to test a similar relationship in the case of former communist states. Hence, our third and last hypothesis is:

H3: There is a positive correlation between the motivations (internal/external) for and benefits (internal/external) of ISO 9001 certification for Bulgaria firms.

\section{Methodology}

\subsection{Approach}

Our study is based on a mixed method research approach, which employed interviews at the exploratory stage and a survey at the descriptive stage. In essence, based on our thorough literature review, we initiated our primary research work with two semi-structured in-depth interviews. The main purpose of the in-depth interviews was to provide additional information on the motivations for ISO 9001 certification that are specific within the context of Bulgaria, as 
well as their relation to both internal and external benefits. The two discussions were detrimental to the development of our hypotheses and were used as the primary base for the second stage of our primary investigation - a survey.

For the purpose of the survey, we developed a standard questionnaire consisting of eight questions. Some of the questions were based on previous research works, whereas others were developed by the authors and were based on their personal experiences in the field of ISO 9001 certification in Bulgaria and the two semi-structured interviews mentioned in the beginning of this section.

\subsection{Sampling}

Our study is predominantly of descriptive nature and employs criterion sampling (Patton, 2001; Palys, 2008) or in other words, cases that meet predetermine criteria. Based on our research objectives, the predetermined criteria are presented in the table below.

Interviews

QMS Auditors (ISO 9001)

At least 5 years of auditing experience in Bulgaria
Survey

Companies registered on the territory of Bulgaria ISO 9001 certified companies

Table 2. Sampling Criteria

Criterion sampling is relevant to our study due to the lack of information in the field of quality management in Bulgaria in general and the ISO certification in particular. Yet another reason for our approach refers to the major discrepancies in terms of the total number of ISO 9001 certified firms on the territory of Bulgaria. For example, according to the International Organization for Standardization, in 2013, the number of such firms stood at 5,378. Yet, according to Club 9000 (the first non-profit nongovernmental organization in the field of quality management in Bulgaria), only 2,768 firms were ISO 9001 certified as of August 2014.

In line with the above facts and the predetermined criteria, we sent an interview invitation to five auditors. For this purpose, we used the business network of one of the two authors of this study, who is also an ISO 9001 certified auditor. Out of the five invitations, two were accepted. The first interview was with the executive director of the Bulgarian Institute for Standardization (BDS), and the second one was with the official representative of AENOR International for Bulgaria (a Spain-based certification entity with offices all over the world) and ISO 9001 leading auditor. 
As to the questionnaire, we used company data provided by BDS and Association 'Club9000'. The questionnaire was distributed electronically to 1,000 ISO 9001 certified firms or approximately $18.6 \%$ of the total ISO 9001 certified population in Bulgaria (International Organization for Standardization, 2013 estimates). The survey included both manufacturing and service-based firms. Further, in order to provide a detailed picture regarding the factors behind ISO 9000 series certification, we involved micro, small, medium, and large firms (for more information regarding the distribution of the companies, see Table 2). Last but not least, we tried to engage representatives from different hierarchical levels including top managers, experts/specialist, shop floor workers, etc. The majority of the questionnaires was addressed by top management personnel $(68.5 \%)$, whilst other major respondents included experts/specialist in the field of quality management and ISO certification (18.1\%).

\begin{tabular}{|c|c|c|}
\hline Field of Activity & Frequency & Percent \\
\hline Manufacturing & 52 & 40.9 \\
\hline Services & 75 & 59.1 \\
\hline Total & 127 & 100 \\
\hline \# of Employees & Frequency & 35.4 \\
\hline Fewer than 10 & 45 & 24.4 \\
\hline Between 10 and 49 & 31 & 21.3 \\
\hline Between 50 and 249 & 27 & 18.9 \\
\hline 250 or more & 24 & 100 \\
\hline Total & 127 & Percent \\
\hline
\end{tabular}

Table 3. Company division by (1) sector/field of activity, and by (2) size/number of employees

\subsection{Data Collection}

The face-to-face interviews were conducted in Bulgarian and took place between June and September 2013. On certain occasions, we also employed email communication; however, such communication was only utilized for the purposes of confirming interview notes and obscurities that resulted within the process of the data analysis. Each interview lasted between one and two, hours, was digitally recorded, and followed a protocol jointly developed by the research team. For more information, refer to the Table 4.

As to the survey, the companies were provided with two options for completing it - (1) online, via a specific online survey platform or (2) email, via the inclusion of a digitally attached file of the survey. All survey questions were presented in Bulgarian language and employed a multiple choice assessment method.

A pilot questionnaire involving fifteen companies was used for pre-testing measures. The pilot questionnaire was launched in the beginning of January 2014 and lasted for three weeks, 
whereas the actual survey took place between February and May 2014. Both the pilot and actual questionnaires were translated from Bulgarian to English and vice versa. The total number of undelivered emails for the entire campaign stood at 52, and was due to outdated contact details. Hence, from the 948 delivered emails, 127 firms responded to our survey invitation, which translates into a response rate of $13.4 \%$.

\begin{tabular}{|c|c|c|c|}
\hline $\begin{array}{l}\text { Theme } \\
\text { (Interview } \\
\text { Guide) }\end{array}$ & Purpose & Interview Questions & $\begin{array}{c}\text { Survey } \\
\text { Question\# }\end{array}$ \\
\hline $\begin{array}{l}\text { Reasons and } \\
\text { motives for } \\
\text { certification } \\
\text { among } \\
\text { Bulgarian } \\
\text { firms }\end{array}$ & $\begin{array}{l}\text { To collect data about } \\
\text { the leading motives } \\
\text { for certification, } \\
\text { thereby allowing for } \\
\text { typological } \\
\text { categorization of the } \\
\text { motives - } \\
\text { internal/external }\end{array}$ & $\begin{array}{l}\text { 1. In line with your observations, what are the main motives } \\
\text { for ISO } 9001 \text { certification? } \\
2 \text {. Based on your personal observations and work experience, } \\
\text { firms from what business sectors are most often opting for } \\
\text { certification? [Follow-up question: What are the main reasons } \\
\text { behind this trend?] } \\
3 \text {. How would you evaluate the overall understanding of QMS } \\
\text { such as ISO } 9001 \text { among Bulgarian managers? } \\
4 \text {. ISO } 9001 \text { is a free-to-implement standard. With this in } \\
\text { mind, how do you perceive the latest trends within the } \\
\text { framework of government biddings in Bulgaria and the } \\
\text { requirements for participation in terms of certification under } \\
\text { ISO } 9001 \text { and/or other standards including ISO } 14001: 2004 \text {, } \\
\text { ISO } 27001: 2013 \text { ? } \\
5 \text {.Top Management Commitment" is an important part of the } \\
\text { ISO } 9001 \text { QMS. Based on your perception, how does the top } \\
\text { management in Bulgaria understand the importance of their } \\
\text { commitment/involvement? Is there an actual commitment } \\
\text { from the top management, or is this commitment merely } \\
\text { based on certification requirements in terms of documentation? } \\
\text { What is the current trend? }\end{array}$ & $\begin{array}{l}\text { Q4 } \\
\text { Q5 } \\
\text { Q6 }\end{array}$ \\
\hline $\begin{array}{l}\text { Development, } \\
\text { implementati } \\
\text { on and } \\
\text { functioning of } \\
\text { QMS, and the } \\
\text { benefits upon } \\
\text { certification }\end{array}$ & $\begin{array}{l}\text { To collect data about } \\
\text { the implementation } \\
\text { and certification of } \\
\text { ISO } 9001 \text {, thereby } \\
\text { allowing for the } \\
\text { typological } \\
\text { categorization of the } \\
\text { benefits } \\
\text { (internal/external) } \\
\text { following ISO } 9001 \\
\text { implementation }\end{array}$ & $\begin{array}{l}\text { 5. How does certification affect business processes after the } \\
\text { first audit: what major changes do you observe during a } \\
\text { surveillance and/or recertification audit? } \\
\text { 6. What are the perceptions and expectations of Bulgarian } \\
\text { businesses towards certification audits? Do these firms } \\
\text { perceive the audit as (1) a test; ( } 2 \text { ) an opportunity to receive } \\
\text { external, yet constructive evaluation; or ( } 3 \text { ) something else? } \\
\text { 7. Have the perception and expectations of Bulgarian firms } \\
\text { towards certification altered in the last few years, and if so, } \\
\text { how? What are the current trends in your opinion? } \\
8 \text {. Does certification affect the quality of products (goods and } \\
\text { services), and if so how? }\end{array}$ & $\begin{array}{l}\text { Q7 } \\
\text { Q8 }\end{array}$ \\
\hline $\begin{array}{l}\text { Firm size and } \\
\text { industry } \\
\text { influence }\end{array}$ & $\begin{array}{l}\text { To collect data about } \\
\text { the potential effects } \\
\text { of firm size and } \\
\text { industry on the } \\
\text { motives for and } \\
\text { benefits of } \\
\text { certification }\end{array}$ & $\begin{array}{l}\text { 9. Do you observe variations in the degree of implementation } \\
\text { and perception of QMS based on firm size and/or industry? } \\
\text { 10. What other trends do you observe? }\end{array}$ & $\begin{array}{l}\text { Q2 } \\
\text { Q3 }\end{array}$ \\
\hline
\end{tabular}

Table 4. Interview Protocol and Framework for Qualitative Analysis

To reduce the risk of bias, the survey was anonymous and guaranteed that no individual responses would be released. Furthermore, due to language and terminology difference, the survey was translated from English to Bulgarian and from Bulgarian to English by native speakers. Finally, the validity of the respondents' opinions was enhanced by the background of both researchers: it is well documented that in the context of research works in former communist states, field research performed by foreigners have posed a great variety of 
obstacles due to the cautious Eastern European cultures (Hill \& McKay, 1988; Faminsky \& Naumov, 1990; Greenberg \& Erdinc, 1999). Hence, by being native Bulgarians, our research has a distinct advantage in terms of reliability. Familiarity with the local culture, language abilities, appearance and status has allowed us to gain easily access to unbiased and valuable information from our interviewees and survey respondents.

\subsection{Variables}

Based on our review of literature and the data gathered through the in-depth interviews, two constructs became the pillars of our survey. For more information please refer to the table below.

\begin{tabular}{|c|c|c|c|}
\hline Construct & \multicolumn{2}{|r|}{ Parameter(s) } & Question \# \\
\hline \multirow{2}{*}{$\begin{array}{l}\text { Reasons for seeking ISO } 9001 \\
\text { certification }\end{array}$} & Internal & (1) Process improvement; (2) Product quality improvement & \multirow{2}{*}{ Q6 } \\
\hline & External & (1) Customer pressure; (2) Enhanced company image & \\
\hline \multirow{3}{*}{$\begin{array}{l}\text { ISO } 9001 \text { impact on company } \\
\text { performance }\end{array}$} & Internal & $\begin{array}{l}\text { (1) Internal/company processes; (2) Employee motivation } \\
\text { and relations; (3) Product quality }\end{array}$ & \multirow{3}{*}{ Q7 } \\
\hline & External & $\begin{array}{l}\text { (1) Relationship with suppliers and subcontractors; (2) } \\
\text { Relationship with current and potential clients; (3) } \\
\text { Relationship with state administration }\end{array}$ & \\
\hline & Other & (1) No major improvements; (2) Negative effect & \\
\hline
\end{tabular}

Table 5. Variables

\subsection{Analysis}

The analysis of the study seeks to test the hypotheses mentioned in the Literature Review section, which, once again, are:

H1: The reasons for obtaining ISO 9001 certification in the case of Bulgarian firms are predominantly external.

H2: In the Bulgarian case, enhanced company image and competitiveness are stronger drivers of ISO 9001 certification than customer and supplier pressures/requirements.

H3: There is a positive correlation between the motivations (internal/external) for and benefits (internal/external) of ISO 9001 certification for Bulgaria firms.

For the purpose of our analysis, we have employed both theoretical and empirical indicators, which are discussed in the table below. As shown below, hypothesis $3(\mathrm{H} 3)$ has been tested by 
employing Cramer's V correlation ( $R), V=\sqrt{\frac{\varphi^{2}}{\min (k-1, r-1)}}=\sqrt{\frac{\chi^{2} / n}{\min (k-1, r-1)}}$ which was determined by IBM SPSS Statistics.

\begin{tabular}{|c|c|c|c|c|}
\hline $\begin{array}{l}\text { Hypothesis } 1 \\
\text { (H1) }\end{array}$ & $\begin{array}{c}\text { Theoretical } \\
\text { Indicators (H1) }\end{array}$ & $\begin{array}{l}\text { Empirical Indicators } \\
\text { (H1) }\end{array}$ & $\begin{array}{l}\text { Criteria for Verification } \\
\text { (H1) }\end{array}$ & $\begin{array}{l}\text { Verification } \\
\text { (H1) }\end{array}$ \\
\hline \multirow{2}{*}{$\begin{array}{l}\text { The reasons for obtaining } \\
\text { ISO } 9001 \text { certification in } \\
\text { the case of Bulgarian } \\
\text { firms are predominantly } \\
\text { external }\end{array}$} & \multirow{2}{*}{$\begin{array}{l}\text { Reasons for } \\
\text { seeking ISO } \\
9001 \text { certification }\end{array}$} & $\begin{array}{l}\text { a) external (i.e. } \\
\text { customer pressure, } \\
\text { enhanced company } \\
\text { image) }\end{array}$ & $\begin{array}{l}\text { If } \mathbf{a} \%-\mathbf{b} \% \geq \mathbf{1 5 \%} \text {, then } \\
\text { external factors are } \\
\text { predominant }\end{array}$ & Accept H1 \\
\hline & & $\begin{array}{l}\text { b) internal (i.e. process } \\
\text { improvement, product } \\
\text { quality improvement) }\end{array}$ & $\begin{array}{l}\text { If } \mathbf{a} \%-\mathbf{b} \%<\mathbf{1 5} \% \text {, then } \\
\text { external factors are NOT } \\
\text { predominant }\end{array}$ & Disprove $\mathrm{H} 1$ \\
\hline $\begin{array}{l}\text { Hypothesis } 2 \\
\text { (H2) }\end{array}$ & $\begin{array}{c}\text { Theoretical } \\
\text { Indicators (H2) }\end{array}$ & $\begin{array}{l}\text { Empirical Indicators } \\
\text { (H2) }\end{array}$ & $\begin{array}{l}\text { Criteria for Verification } \\
\text { (H2) }\end{array}$ & $\begin{array}{l}\text { Verification } \\
\text { (H2) }\end{array}$ \\
\hline \multirow{2}{*}{$\begin{array}{l}\text { In the Bulgarian case, } \\
\text { enhanced company } \\
\text { image and } \\
\text { competitiveness are } \\
\text { stronger drivers of ISO } \\
9001 \text { certification than } \\
\text { customer and supplier } \\
\text { pressures/requirements }\end{array}$} & \multirow{2}{*}{$\begin{array}{l}\text { Reasons for } \\
\text { seeking ISO } \\
9001 \text { certification }\end{array}$} & $\begin{array}{l}\text { a) Enhanced company } \\
\text { image and } \\
\text { competitiveness }\end{array}$ & $\begin{array}{l}\text { If } \mathbf{a}-\mathbf{b}>\mathbf{0} \text {, then } \\
\text { enhanced company image } \\
\text { and competitiveness is a } \\
\text { stronger driver than } \\
\text { customer and supplier } \\
\text { requirements/pressure }\end{array}$ & Accept H2 \\
\hline & & $\begin{array}{l}\text { b) Customer and } \\
\text { supplier } \\
\text { requirements/pressure }\end{array}$ & $\begin{array}{l}\text { If } \mathbf{a}-\mathbf{b}<\mathbf{0} \text {, then } \\
\text { customer and supplier } \\
\text { requirements/pressure is } \\
\text { a stronger driver than } \\
\text { enhanced company image } \\
\text { and competitiveness }\end{array}$ & Disprove $\mathrm{H} 2$ \\
\hline $\begin{array}{l}\text { Hypothesis } 3 \\
\text { (H3) }\end{array}$ & $\begin{array}{c}\text { Theoretical } \\
\text { Indicators (H3) }\end{array}$ & $\begin{array}{l}\text { Empirical Indicators } \\
\text { (H3) }\end{array}$ & $\begin{array}{l}\text { Criteria for Verification } \\
\text { (H3) }\end{array}$ & $\begin{array}{l}\text { Verification } \\
\text { (H3) }\end{array}$ \\
\hline \multirow{2}{*}{$\begin{array}{l}\text { There is a positive } \\
\text { correlation between the } \\
\text { motivations } \\
\text { (internal/external) for } \\
\text { and benefits } \\
\text { (internal/external) of ISO } \\
9001 \text { certification for } \\
\text { Bulgarian firms }\end{array}$} & $\begin{array}{l}\text { a) Reasons for } \\
\text { seeking ISO } \\
9001 \text { certification }\end{array}$ & \multirow{2}{*}{$\begin{array}{l}\text { Cramer's V correlation } \\
\text { analysis between a) and } \\
\text { b) }\end{array}$} & $R>0.3$ & Accept H3 \\
\hline & $\begin{array}{l}\text { b) Organizational } \\
\text { aspects positively } \\
\text { influenced by } \\
\text { certification }\end{array}$ & & $\mathbf{R}<0.3$ & Disprove $\mathrm{H} 3$ \\
\hline
\end{tabular}

Table 6. Framework for Analysis \& Criteria for Hypothesis Verification

Based on Table 6, two important issues must be addressed. First of all, In terms of $\mathrm{H} 1$ and the criteria for verification, we have defined a minimum difference of $15 \%$ between the external and internal reasons for ISO 9001 certification. The choice of the percentage value is based on the application of the word 'predominantly' in $\mathrm{H} 1$. Second of all, due to the non-random nature of our sample, Pearson's chi-squared test was not used in the verification of $\mathrm{H} 3$.

\subsection{Validity and Reliability}

The soundness of the data collected through the semi-structured, in-depth interviews was delivered in two ways. Firstly, as noted above, both interviewees were experts in the field of QMS certification with over ten years of experience in Bulgaria. Secondly, as depicted by Table 
4 below, the questions addressed during the interviews were specifically designed to unveil important data about the motives for and benefits of ISO 9001 certification in Bulgaria, on which the questionnaire was based.

Due to the low response rate $-13.4 \%$, to estimate the effect of non-response on our study, a non-response bias check was generated (Armstrong \& Overton, 1977). For this purpose, we used the following two known database variables/characteristics: (1) company by sector and (2) company by size. As presented by the table below, no significant bias was observed.

\begin{tabular}{|c|c|c|c|c|}
\hline \multirow{2}{*}{ Company by sector } & \multirow{2}{*}{ Entire Sample } & \multirow{2}{*}{ Respondents } & \multicolumn{2}{|c|}{ Non-respondents } \\
\hline & & & Refusals & Undelivered \\
\hline Manufacturing & $400(40.0)$ & $52(40.9)$ & $328(40.0)$ & $20(38.5)$ \\
\hline Services & $600(60.0)$ & $75(50.1)$ & $493(60.0)$ & $32(61.5)$ \\
\hline Total & 1000 & 127 & 821 & 52 \\
\hline \multirow{2}{*}{ Company by size } & \multirow{2}{*}{ Entire Sample } & \multirow{2}{*}{ Respondents } & \multicolumn{2}{|c|}{ Non-respondents } \\
\hline & & & Refusals & Undelivered \\
\hline Fewer than 10 & $350(35.0)$ & $45(35.4)$ & $285(34.7)$ & $20(38.5)$ \\
\hline Between 10 and 49 & $250(25.0)$ & $31(24.4)$ & $205(25.0)$ & $14(26.9)$ \\
\hline Between 50 and 249 & $200(20.0)$ & $27(21.3)$ & $163(19.9)$ & $10(19.2)$ \\
\hline 250 or more & $200(20.0)$ & $24(18.9)$ & $168(20.5)$ & $8(15.4)$ \\
\hline Total & 1000 & 127 & 821 & 52 \\
\hline
\end{tabular}

NB: Percentage in parentheses

Table 7. Differences of respondents VS non-respondents

Finally, as noted above, for the verification of hypothesis 3 (H3), we use Cramer's V correlation. The verification method's choice was based on the nature of the questionnaire: all questions in this study were based on qualitative indicators. Therefore, by applying Cramer's $\mathrm{V}$ correlation, we determined the strength of the correlation between the qualitative indicators (1) motivations and (2) benefits of ISO 9001 certification.

\section{Findings and Discussions}

In this section, the empirical findings related to the two main constructs of our study are discussed. We initiate the discussion with (1) the 'motivational factors for ISO 9001 certification'. From there, we proceed with (2) the 'company aspects influenced by ISO 9001 certification', and we conclude this section with an examination of (3) the relationship between the motivations and benefits of ISO 9001 certification. 


\subsection{Motivations for Adoption of ISO 9000 Family of Standards}

Figures 1 and 2 depict the main motivational factors for ISO 9001 certification based on our sample. The largest group of respondents (50 companies or $39.4 \%$ of the total sample) pointed enhanced company image and competitiveness as the main motivational factor, which according to our literature review belongs to the so-called external factors. The second most often cited reason for ISO 9001 implementation in Bulgaria is process improvement - an internal factor supported by 37 firms or $29.1 \%$ of the entire sample.

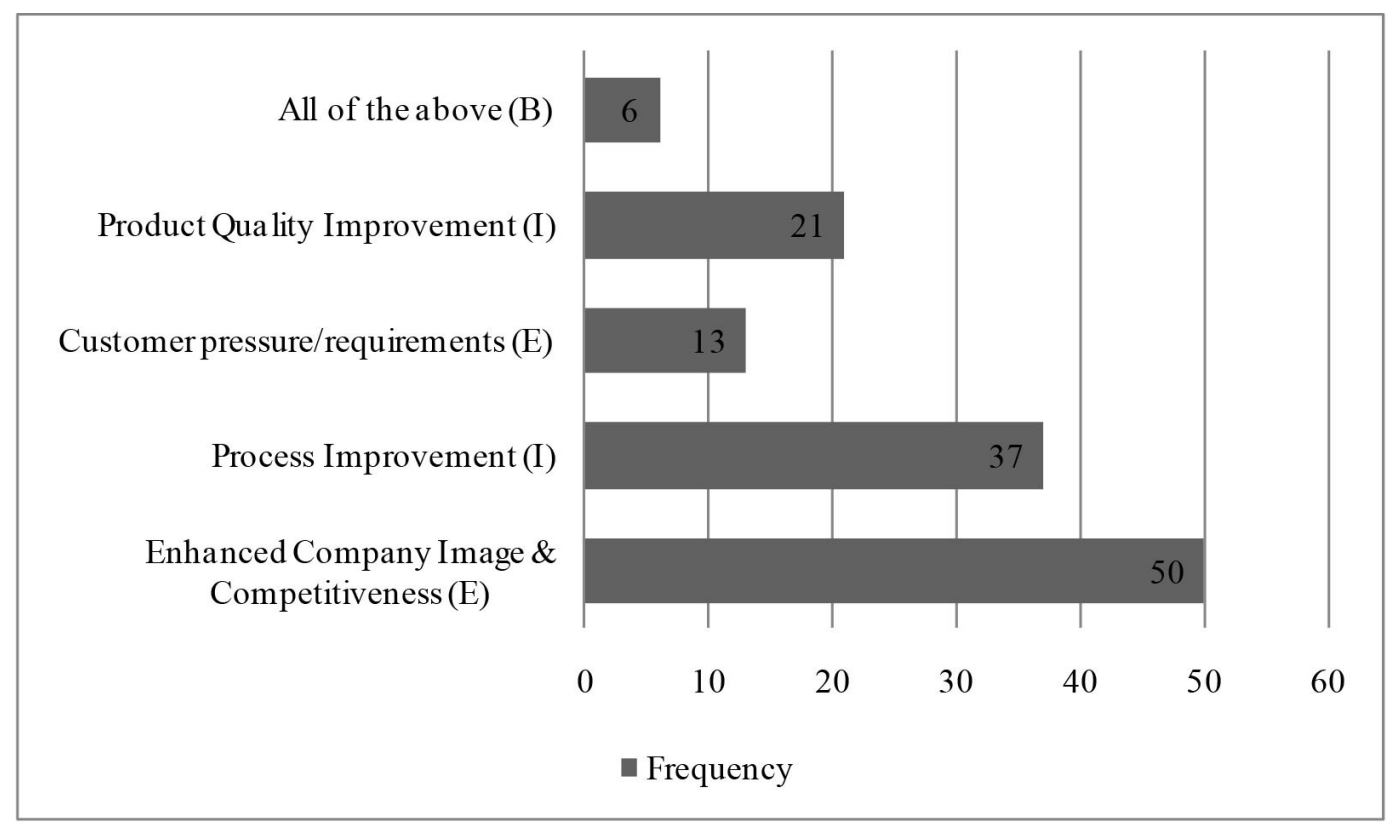

*Legend (I - Internal Factor; E - External Factor; B - Both)

Figure 1. Motivational factors for ISO 9001 certification

Based on the results mentioned above, we can assert that as in the case of other developing economies, the bulk of Bulgarian firms pursue ISO standardization driven by the desire to create a favourable image among clients, especially foreign ones (Otsuki, 2011). Nevertheless, our study's empirical findings are somewhat different from those asserted by Ruzevicius et al. in their study of Lithuanian ISO 9001 certified companies (Ruzevicius et al., 2004). Even though both countries share similar historical, political and economic background (Bulgaria and Lithuania were communist states, which in the 1990s adopted the market economy approach, and later on joined NATO and the European Union), we observe a clear distinction in the motivations for ISO 9001 certification. The bulk of Lithuanian firms are internally driven more than $70 \%$ of them stated 'ensured constant quality level manufacturing' as the main reason for ISO 9001 implementation. On the other side, only $16.5 \%$ of our respondents addressed similar reasons. 
These results raise a very important concern about the overall understanding of the quality movement in former communist states, where the predominant view has declared strong similarities among these countries. The notion that 'the centrally-planned system had a strong homogenizing effect not only on enterprise management, but also on education, culture, and more (White, 1991; Fontaine, 1996; Liuhto, 1999) might have been valid ten-fifteen years ago, but now requires strong reconsideration, it seems.

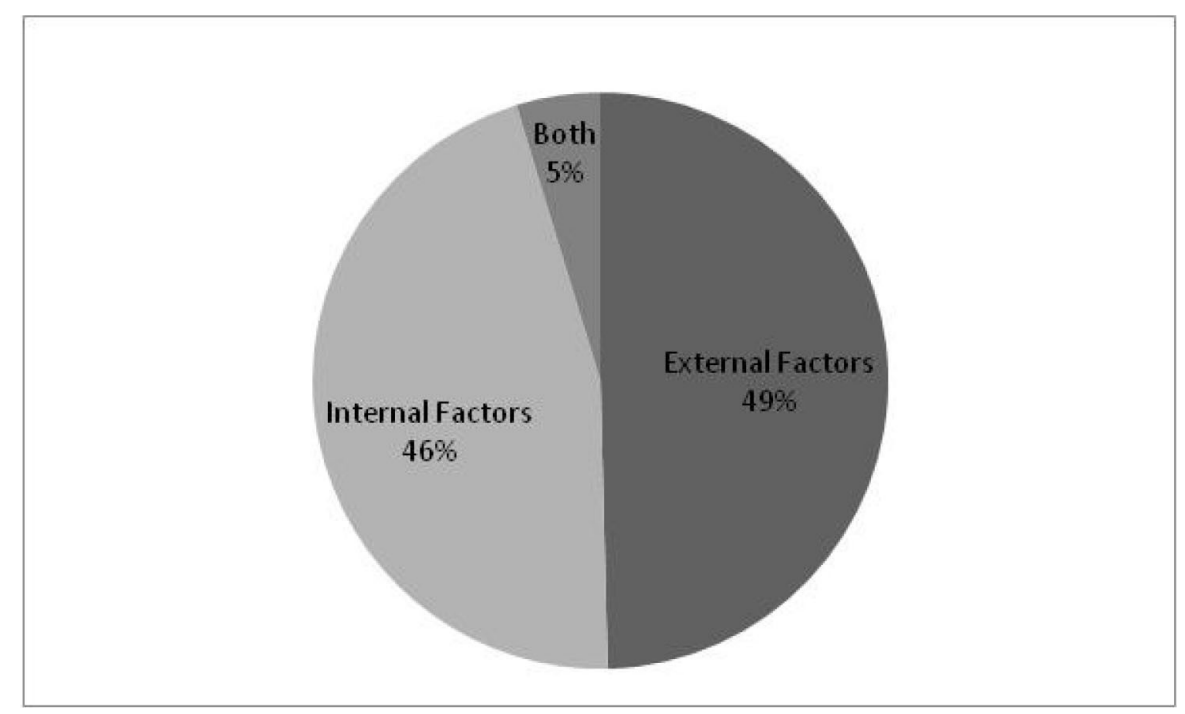

Figure 2. ISO 9001 certified firms driven by internal/external motivations (Internal VS External)

Further, regardless of the afore-mentioned results, based on the overall division by internal and external factors (Figure 2), the motives for ISO 9001 adoption in the case of our sample are not predominantly external. In fact, our empirical findings reveal incremental difference between the number of internally-driven and externally-driven firms in the case of our sample - $46 \%$ versus $49 \%$. Hence, based on the criteria outlined in table 5 , our first hypothesis 'H1: The reasons for obtaining ISO 9001 certification in the case of Bulgarian firms are predominantly external' is disproved. Regardless of this outcome, as we emphasized before, the leading motivation for ISO 9001 certification in our case is an external one - enhanced company image and competitiveness. Therefore, to deepen our discussion, two additional important observations in the case of former communist economies and Bulgaria in particular must be addressed.

First, from a theoretical point of view, external motivation can be discussed from the point of economic sociology and neo-institutionalism in particular. According to the neo-institutional theory addressed by Meyer and Rowan (1977), DiMaggio and Powell (1983), Powell and DiMaggio (1991), Scott (1995), and Greenwood, Oliver, Sahlin-Andersson and Suddaby (2012), organizations are embedded in institutional environments in which various belief 
systems of goals and control systems exist, and through which organizational goals can be achieved. In this perspective, it seems that organizations are shaped by external pressures, and this notion applies strongly in the field of quality management and ISO certification per se. Hence, to a large extend ISO 9001 certification in Bulgaria is perceived by many as a marketing tool. This trend can be described as mimetic isomorphism (DiMaggio \& Powell, 1983), which is created by a desire for support and legitimacy within the institutional fields, in which these organizations operate (Vasconcelos \& Vasconcelos, 2003). In other words, mimetic isomorphism arises where organizations imitate the behaviour of others (Rosenkopf \& Abrahamson, 1999). This is, however, not surprising, for as we mentioned before, former communist states such as Bulgaria suffer from the image of low quality producers.

Second, based on our empirical data, we claim that institutional pressures are likely to play a leading role in the diffusion of ISO 9001 in the case of Bulgarian firms, when it comes to clearly expressed external motivations. On the other side, however, the neo-institutional approach is not relevant in the case of firms dominated by internal motivations. Fortunately, a plethora of new empirical evidence suggests a theoretical framework for relevant explanations o f internal motives for ISO 9001 certification. According to this evidence, adoption of management standards such as ISO 9001 can provide more than just legitimacy. It can help firms improve internal processes by reducing transaction costs (Almeida et al. 2009; Okay \& Semiz, 2010; Saleem, Siddique, Akmal, Masud Khan, Usman Khan \& Sultan, 2011; Iwaro \& Mwasha, 2012; Al-Refaie et al., 2012), increase business efficiency (Kawthar \& Vinesh, 2011), and favour foreign direct investment (Xun Cao \& Prakash, 2007; Boys \& Grant, 2009; Blind \& Mangelsdorf, 2012). Hence, it is possible to assume that internal motives as such as "process improvement" and "product quality improvement practices" are associated with similar aspirations. Nevertheless, the afore-mentioned statements must be verified via further empirical research.

Finally, one additional imperative point must be emphasized - the substantial difference between the two external parameters, namely (1) enhanced company image and competitiveness and (2) customer and supplier pressure/requirements. Based on the results depicted in Figure 1, the first external parameter is almost four times stronger than the second one. The result is in line with our second hypothesis - H2: In the Bulgarian case, enhanced company image and competitiveness are stronger drivers of ISO 9001 certification than customer and supplier pressures/requirements. This result is not specific to Bulgaria only: a number of international research works have shown similar results. For example, enhanced company image and competitiveness is a leading motivational factor for ISO 9001 certification in the case of the U.S. and Canada - Anderson et al. (1999), Spain - Llopis and Tarí (2003), Lithuania - Ruzevicius et al. (2004), Brazil - Almeida et al. (2009), Saudi Arabia - Kadash (2012), and so on. A possible explanation for this result may be the idea that certification represents an attempt to communicate about desirable organizational attributes to parties that cannot observe them directly. In this line of thoughts, certification under the ISO 9001 
standard driven by enhanced company image and competitiveness is seen as a specific mechanism for the creation of impersonal trust (Shapiro, 1987). In other words, certification reduces uncertainty, making firms predictable partners in inter-firm relations (see Grajek, 2004; Terlaak \& King, 2006; Goedhuys \& Sleuwaegen, 2011; Heras-Saizarbitoria \& Boiral, 2012; Angheluţa, Pirnea \& Moisa, 2012). This seems to be a logical explanation in the case of Bulgaria and other former Eastern Bloc states, which suffer from the image of low quality brought by the unfortunate Soviet legacy.

\subsection{ISO 9001 Impact on Company Performance}

The second area of our concern was the ISO 9001 impact on company performance such as internal processes; relationship with current and potential clients; relationship with suppliers and subcontractors, etc. The largest group of respondents (46 firms or $36.2 \%$ ) referred t o internal processes (i.e. communication, business structuring) as the most positively influenced aspect of their company. The second construct that experienced major positive effects referred to the relationship with current and potential clients - 28 or $22 \%$ of the respondents agree that since the ISO certification their liaisons with customers have significantly improved. Overall, our study reveals significantly stronger effect on internal factors (i.e. process improvement) in comparison with external ones (i.e. relationship with current and potential clients).

A plausible explanation to this occurrence might be the relatively ineffective management style and the low product quality that were akin to most CEE states, especially the Eastern European ones (i.e. Bulgaria), after the end of communism. Thus, the opening of the markets and the followed introduction of new management approaches including quality management ones (i.e. ISO 9001 QMS) in the last decade must have contributed to improvements in internal processes, product quality, and so on.

It is also imperative to mention that a number of firms $-4.7 \%$ of all respondents - reported negative results upon certification such as increased bureaucracy, negative impact on management, practices, etc. Plausible explanations include ISO 9000 series' common criticism such as the amount of money, time, and paperwork required for registration (Anderson et al., 1999; Boiral, 2003; Kumar \& Balakrishnan, 2011). 


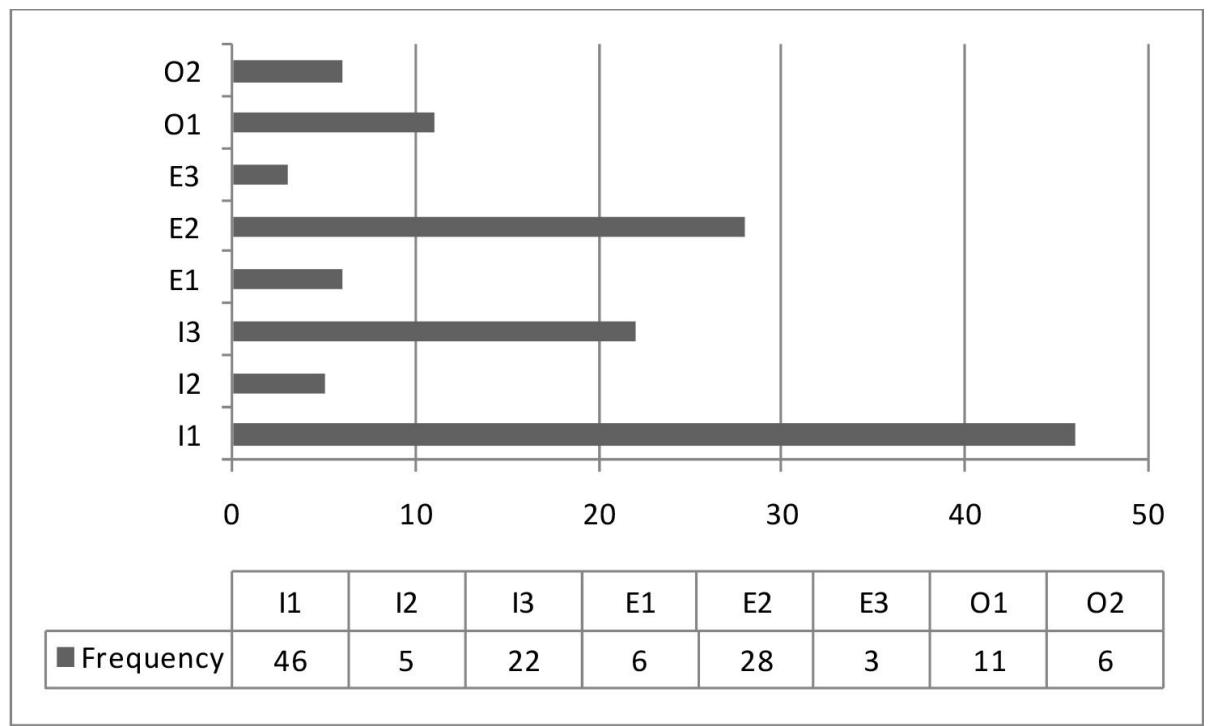

*Legend (I - Internal Factor; E - External Factor; O - Other)

\begin{tabular}{|l|c|}
\hline \multicolumn{1}{|c|}{ Company Aspects } & Legend \\
\hline Internal processes & I1 \\
\hline Employee motivation and relations & I2 \\
\hline Product Quality & I3 \\
\hline Relationship with suppliers and subcontractors & E1 \\
\hline Relationship with current and potential clients & E2 \\
\hline Relationship with state administration & E3 \\
\hline No major changes/improvements were observed & O1 \\
\hline $\begin{array}{l}\text { The overall effect was predominantly negative (i.e. increased } \\
\text { bureaucracy, negative impact on management, practices) }\end{array}$ & O2 \\
\hline
\end{tabular}

Figure 3. Impact of ISO 9001 on company performance

\subsection{Motivations and Benefits of ISO 9001 Certification}

Proceeding with our findings, we analyzed the relationship between motivations and benefits of ISO 9001 certification. As we noted in the Literature Review part, previous studies from different parts of the world (i.e. Taiwan, Portugal) have indicated that firms driven by external motivations report a greater number of external benefits than firms driven by internal motivations and vice versa (Heras-Saizarbitoria et al., 2001; Gotzamani \& Tsiotras (2002); Llopis \& Tarí, 2003; Ruzevicius et al., 2004; Martínez-Costa et al., 2008; Kaziliūnas, 2010; Kawthar \& Vinesh, 2011).

Based on our sample, firms' expectations in terms of ISO 9001 certification were in line with the results upon the certification itself. For example, those companies who were seeking the introduction of product quality improvement practices through ISO 9001 certification reported positive changes in terms of product quality; those who were seeking process improvement reported increased efficiency in terms of daily operations and management; and lastly, those 
firms who were seeking enhanced company image and competitiveness reported better relationship with current and potential clients. Hence, we checked the correlation between the motivations and benefits of ISO 9001 certification in the case of Bulgaria: based on Cramer's V correlation analysis, the results are depicted below (Table 8 ).

\begin{tabular}{|l|c|c|}
\hline \multicolumn{1}{|c|}{ Sample } & Value of the Correlation Co-Efficient & Strength of the Correlation \\
\hline Entire Sample & 0.318 & Moderate $(0.3-0.5)$ \\
\hline Manufacturing Only & 0.385 & Moderate $(0.3-0.5)$ \\
\hline Services Only & 0.394 & Moderate $(0.3-0.5)$ \\
\hline
\end{tabular}

Table 8. Correlation between Motivations for and Benefits of ISO 9001 certification

In essence, the empirical findings of our study reveal moderate correlation between the motivations and benefits of ISO 9001 certification, whereas in the case of the service-oriented firms in our sample, the correlation seems to be the strongest -0.394 . In line with the results presented in Table 8 and the criteria for the verification of hypothesis 3 outlined in Table 6, we accept H3, which states a positive correlation between the motivations (internal/external) for and benefits (internal/external) of ISO 9001 certification in Bulgaria. A number of studies from the last fifteen years or so have exhibited similar results (see Gotzamani \& Tsiotras, 2002; Poksinska et al., 2002; Williams, 2004; Martínez-Costa et al., 2008; Kaziliūnas, 2010; Santos \& Millán, 2013).

\section{Conclusions}

This piece of work is the result of an empirical study formulated by theoretical and primary research works of leading international scientists and researchers in the last two decades. The goal of the study was to present Bulgaria on the world map for ISO certification for the first time, and more precisely to look into the motivational factors for ISO 9001 certification from the dual model or in other words from the internal/external motivations perspective. Additionally, the study sought to verify the relationship between motivations and benefits of ISO 9001 certification. Hence, based on our findings generated by a sample of 127 ISO 9001 certified firms in Bulgaria, the following results were reported:

1. Even though the bulk of the firms included in our sample claimed ISO 9001 certification driven by enhanced company image and competitiveness-an external motivation, the overall difference in terms of numbers between the externally driven and internally driven firms was extremely small. This result was not in line with our initial expectations, hence our first hypothesis was disproved. In this course of light, based on 
our sample, we conclude that the motivation aspect of ISO 9001 certification can be described as heterogeneous, or in other words almost equally external and internal.

2. Our second hypothesis - (H2) In the Bulgarian case, enhanced company image and competitiveness are stronger drivers of ISO 9001 certification than customer and supplier pressures/requirements - was confirmed. In line with our findings, among Bulgarian firms, we observed a clearly defined desire for support and legitimacy within the institutional fields, in which these entities operate.

3. Our correlation analysis revealed a moderate, yet positive relationship between the motivations and benefits of ISO 9001 certification. Based on our sample, firms that are mainly externally driven reported most often improvements in the context of external benefits, and firms that are predominantly internally driven recorded a higher number of improvements in the context of internal benefits.

\section{Limitations and Further Research}

As noted in the Introduction part, this study employs criterion sampling. Hence, the presented results and analyses of the gathered data are only valid for the sample. In line with this, generalizing in the case of the entire ISO 9001 population in Bulgaria should be carefully considered. Yet, until notable improvements in the availability and accuracy of the statistical data provided by the leading institutions in the country take place, the outcomes put forth in this paper can serve as a strong basis for understanding the reasons for adoption and the benefits of ISO 9001 in Bulgaria.

The constructs based on the internal/external model presented in this paper represent a major part of the main motivations for certification, yet in case of future research, the model can be expanded by including other, not so common constructs. Furthermore, considering the deductive approach of our study, in the future, it would be interesting to establish a cause-and-effect relationship between the motives and benefits in a more profound manner by involving explanatory models as part of the institutional environment and the socioeconomic characteristics of Bulgarian businesses. 


\section{References}

Abraham, M., Crawford, J., Carter, D., \& Mazotta, F. (2000). Management decisions for effective ISO 9000 accreditation. Management Decision, 38(3), 182-193.

http://dx.doi.org/10.1108/EUM0000000005346

Abramuszkinova, E., \& Kuřitkova, I. (2013). Certification of Corporate Social Responsibility in the Czech Republic. Acta Universitatis Agriculturae et Silviculturae Mendelianae Brunensis, 61(7), 1933-1940. http://dx.doi.org/10.11118/actaun201361071933

Al-Refaie, A., Ghnaimat, O., \& Li, M. (2012). Effects of ISO 9001 Certification and KAAE on Performance of Jordanian Firms. Jordan Journal of Mechanical and Industrial Engineering, $6(1), 45-53$.

Almeida, M., Caten, C., \& Gutterres, M. (2009). Evaluating ISO 9001:2000 Certified and NonCertified Organizations in Brazilian Leather-Footwear Chain. Brazilian Journal of Operations \& Production Management, 6(2), 51-73.

Alolayan, S., Hashmi, S., Yilbas, B., \& Hamdy, H. (2013). An Empirical Evaluation of the ISO 9001 Quality Management Systems for Certified Work Organizations in Kuwait as Benchmarked against Analogous Swedish Organizations. Journal of Service Science and Management, 6, 80-95. http://dx.doi.org/10.4236/jssm.2013.61009

Anderson, S.W., Daly, J.D., \& Johnson, M.F. (1999). Why Firms Seek ISO 9000 Certification: Regulatory Compliance or Competitive Advantage? Production and Operations Management, $8(1), 28-43$.

Angheluţa, T., Pirnea, I., \& Moisa, C. (2012). Quality System Implementation Process for Sustainable Success Development in Romanian SMEs. Economy Transdisciplinarity Cognition, 15(1), 226-232.

Arauz, R., \& Suzuki, H. (2004). ISO 9000 performance in Japanese industries. Total Quality Management \& Business Excellence, 15(1), 3-33. http://dx.doi.org/10.1080/1478336032000149072

Armstrong, J.S., \& Overton, T.S. (1977). Estimating nonresponse bias in mail surveys. Journal of Marketing Research, 396-402. http://dx.doi.org/10.2307/3150783

Association "Club 9000". (2014). Viewed 03 August 2014. http://www.club9000.org/

Beck, N., \& Walgenbach, P. (2003). ISO 9000 And Formalization-How Organizational Contingencies Affect Organizational Responses To Institutional Forces. Schmalenbach Business Review, 55, 293-320. 
Bhuiyan, N., \& Alam, N. (2004). ISO 9001: 2000 implementation-the North American experience. International Journal of Quality \& Reliability Management, 53(1), 10-17. http://dx.doi.org/10.1108/17410400410509923

Blind, K., \& Mangelsdorf., A. (2012). The Trade Impact of ISO 9000 Certifications and International Cooperation in Accreditation. EURAS Conference, Košice, 18-20 June.

Boiral, O. (2003). ISO 9000: outside the iron cage. Organization Science, 14(6), 720-737. http://dx.doi.org/10.1287/orsc.14.6.720.24873

Boulter, L., \& Bendell, T. (2002). How can ISO 9000: 2000 help companies achieve excellence?: What the companies think. Measuring business excellence, 6(2), 37-41. http://dx.doi.org/10.1108/13683040210431455

Boys, K., \& Grant, J. (2009). ISO 9000 Standards: Implicit Barrier or Trade Facilitation Strategy? Agricultural and Applied Economics Association, Annual Meeting. Milwaukee, Wisconsin, July 26-28.

Braun, B. (2005). Building global institutions: the diffusion of management standards in the world economy - an institutional perspective'. In Alvstam, C.G. \& Schamp, E.W. (Eds), Linking Industries Across the World, Ashgate, London, pp.3-27.

Brown, A., Van der Wiele, T., \& Loughton, K. (1998). 'Smaller Enterprises' Experiences with ISO 9000. International Journal of Quality \& Reliability Management, 15(3), 273-285. http://dx.doi.org/10.1108/02656719810198935

Buttle, F. (1997). ISO 9000: Marketing motivations and benefits. International Journal of Quality \& Reliability Management, 14(9), 936-947. http://dx.doi.org/10.1108/02656719710186867

Cagnazzo, L., Taticchi, P., \& Fuiano, F. (2010). Benefits, barriers and pitfalls coming from the ISO 9000 implementation: the impact on business performances. Wseas Transactions On Business And Economics, 4(7), 311-321.

Casadesús, M., \& Jiménez, G. (2000). The Benefits of the Implementation of the ISO 9000 Standard: Empirical Research in 288 Spanish Companies. The TQM Magazine, 12(6), 432-441. http://dx.doi.org/10.1108/09544780010351751

Casadesús, M., \& Karapetrovic, S. (2005). Has ISO 9000 lost some of its luster? A longitudinal impact study. International journal of operations \& production management, 25(6), 580-596. http://dx.doi.org/10.1108/01443570510599737

Casadesús, M., Giménez, G., \& Heras, I. (2001). Benefits of ISO 9000 implementation in Spanish industry. European Business Review, 13(6), 327-336.

http://dx.doi.org/10.1108/EUM0000000006195 
Castka, P., Balzarova, M., \& Kenny, J. (2006). Survey of ISO 9000 users in New ZealandDrivers and Benefits, ISO 9000/14000 Research Project. Viewed 22 September 2014, http://www.mang.canterbury.ac.nz/research/iso/index.shtml

Chankova, L. (2006). Quality Management Systems (ISO 9000) and logistics in industrial firms in Bulgaria. Economic Alternatives, 3, 24-40.

Corbett, C., Luca, A., \& Pan, J. (2003). Global perspectives on global standards. ISO Management Systems (January-February).

Diaye, M., Jovanovic, J., Krivokapic, Z., Pekovic, S., \& Vujovic, A. (2008). Difficulties in ISO 9001 implementation in Manufacturing and Service Organizations: Empirical Evidence from Serbia-Montenegro.

DiMaggio, P., \& Powell, W. (1983). The Iron Cage Revisited: Institutional Isomorphism and Collective Rationality in Organizational Fields. American Sociological Review, 48, 147-160. http://dx.doi.org/10.2307/2095101

Dongmo, C., \& Onojaefe, D. (2013). Using customer satisfaction to understand implementation benefits of the ISO 9001 quality management system. Business Management Dynamics, $3(3), 1-9$.

Ebrahimpour, M., Withers, B., \& Hikmet, N. (1997). Experiences of US and Foreign-Owned Firms: a New Perspective on ISO 9000 Implementation. International Journal of Production Research, 37(2), 567-576.

Escanciano, C., Fernández, E., \& Vázquez, C. (2001). ISO 9000 certification and quality management in Spain: results of a national survey. The TQM Magazine, 13(3), 192-200. http://dx.doi.org/10.1108/09544780110385500

Faminsky, I., \& Naumov, A. (1990). Historical Review of USSR Economic Institutions since the Revolution. Behind the Factory Walls: Decision Making in Soviet and US Enterprises, ed. by P. Lawrence, \& C. Vlachoutsicos, 43-52.

Fontaine, R., (1996). Red Phoenix Rising? Dealing with the Communist Resurgence in Eastern Europe. Cato Institute.

Goedhuys, M., \& Sleuwaegen, L. (2011). The role of international quality standards certification for firms in institutionally weak countries. Globelics International Conference edition. Buenos Aires (Argentina), 15-17 November.

Gotzamani, K., \& Tsiotras, G. (2002). The true motives behind ISO 9001 certification: Their effect on the overall certification benefits and long term contribution towards TQM. International Journal of Quality \& Reliability Management, 19(2), 151-169. 
Grajek, M. (2004). Diffusion of ISO 9000 Standards and International Trade. Wissenschaftszentrum Berlin. CIG Working Papers. SP II 2004-16.

http://dx.doi.org/10.2139/ssrn.650703

Greenberg, E., \& Erdinc, D. (1999). Corporate Culture in Transition: Case Study Evidence from Bulgaria. American University in Bulgaria.

Greenwood, R., Oliver, C., Sahlin-Andersson, K, \& Suddaby, R. (2012). Institutional Theory in Organization Studies. London: SAGE Publications Ltd.

Gupta, A. (2000). Quality management practices of ISO vs non-ISO companies: A case of Indian industry. Industrial Management and Data Systems, 100(9), 451-455.

http://dx.doi.org/10.1108/02635570010358357

Gustafsson, R., Klefsjo, B., Berggren, E., \& Granfors-Wellemets, U. (2001). Experiences from implementing ISO 9000 in small enterprises-a study of Swedish organisations. The TQM Magazine, 13(4), 232-246. http://dx.doi.org/10.1108/09544780110366088

Hardjono, T.W., Ten Have, S., \& Ten Have, W.D. (1997). The European Way to Excellence. How 35 European manufacturing, public and service organizations make use of quality management. European commission.

Heras-Saizarbitoria, I., \& Boiral. O. (2012). Is ISO 9001 really effective for the global supply chain management? A Preliminary exploratory analysis on customer-suppliers relationships in China. Mercès, B. (Ed.). Quality management and beyond: the current situation and future perspectives. Catalunya: Documenta Universitaria, 29-41.

Heras-Saizarbitoria, I., Arana, G., \& San Miguel, E. (2010). An Analysis of the Main Drivers for ISO 9001 and other Isomorphic Metastandards. Review of International Comparative Management, 11(4), 562-574.

Heras-Saizarbitoria, I., Casadesús, M., \& Ochao, C. (2001). Effects of ISO 9001 certification on companies' profitability: an empirical study. Integrated Management. Proceedings of the 6th International Conference on ISO 9000 and TQM, 60-65.

Hill, M., \& McKay, R. (1988). Soviet Product Quality. St. Marten's Press, New York.

Ismail Salaheldin, S. (2003). The implementation of TQM strategy in Egypt: a field-force analysis. The TQM Magazine, 15(4), 266-274. http://dx.doi.org/10.1108/09544780310486173

ISO (1996). Retrieved 02 January 2014, http://www.iso.org/iso/home/standards/certification/isosurvey.htm

Iwaro, J., \& Mwasha, A. (2012). The effects of ISO certification on organization workmanship performance. Quality Management Journal, 2012, 19(1), 53-67. 
Jang, W., \& Lin, Ch. (2008). An integrated framework for ISO 9000 motivation, depth of ISO implementation and firm performance. The case of Taiwan. Journal of Manufacturing Technology Management, 19(2), 194-216. http://dx.doi.org/10.1108/17410380810847918

Jones, R., Arndt, G., \& Kustin, R. (1997). ISO 9000 among Australian companies: impact of time and reasons for seeking certification on perceptions of benefits received. International Journal of Quality \& Reliability Management, 14(7), 650-660.

http://dx.doi.org/10.1108/02656719710173258

Kadasah, N. (2012). An Empirical Study of the Benefits of ISO 9000 Implementation in the Private Sector in Saudi Arabia. European Journal of Economics, Finance and Administrative Sciences, 49, 18-27.

Kaminski, B., \& Ng, F. (2006). Bulgaria's Integration into the Pan-European Economy and Industrial Restructuring. World Bank Policy Research. Working Paper, 3863.

Kawthar, M., \& Vinesh, S. (2011). The Impact of ISO 9000 Certification on Sales: A Case Study of Mauritius. TIPS Small Grant Scheme Research Paper Series.

Kaziliūnas, A. (2010). The Implementation of Quality Management Systems in Service Organizations. Viešoji politika ir administravimas, 34, 71-82.

Kostagiolas, P., \& Kitsiou, M. (2008). Issues and perceptions for ISO 9000 implementation in Greek academic libraries. Library Management, 29, 6(7), 57-64.

http://dx.doi.org/10.1108/01435120810894572

Kumar, D., \& Balakrishnan, V. (2011). A Study on ISO 9001 Quality Management System Certifications-Reasons behind the Failure of ISO Certified Organizations. Global Journal of Management and Business Research, 11(9).

Lee, S., Luthans, F., \& Hodgetts, R. (1992). Total quality management: Implications for Central and Eastern Europe. Organizational Dynamics, 20(4), 42-55. http://dx.doi.org/10.1016/00902616(92)90074-W

Leung, N.K.H., Lee, H.H. \& Chan, C.C.K. (1999). Costs and benefits of ISO 9000 series: A practical study. International Journal of Quality \& Reliability Management, 16(7), 675-690. http://dx.doi.org/10.1108/02656719910283362

Liebesman, S. (2002). Implementing ISO 9001: 2000-US survey of user experiences. ISO Management Systems (November-December).

Lipovatz, D., Stenos, F., \& Vaka, A. (1999). Implementation of ISO 9000 quality systems in Greek enterprises. International Journal of Quality \& Reliability Management, 16(6), 534-551. http://dx.doi.org/10.1108/02656719910278575 
Liuhto, K. (1999). The Transformation of the Soviet Enterprise and its Management: $A$ Literature Review. ESRC Centre for Business Research, Department of Applied Economics, University of Cambridge.

Llopis, J., \& Tarí, J. (2003). The importance of internal aspects in quality improvement. International Journal of Quality \& Reliability Management, 20(3), 304-324.

http://dx.doi.org/10.1108/02656710310461314

Magd, H., \& Curry, A. (2003). ISO 9000 and TQM: Are they complementary or contradictory to each other?. The TQM magazine, 15(4), 244-256. http://dx.doi.org/10.1108/09544780310486155

Magd, H., \& Curry, A. (2008). The importance of internal aspects in quality improvement. International Journal of Quality \& Reliability Management, 20(2), 304-324.

Martínez-Costa, M., Martínez-Lorente, A., \& Choi, T. (2008). Simultaneous consideration of TQM and ISO 9000 on performance and motivation: An empirical study of Spanish companies. International Journal of Production Economics, 113(1), 23-39.

http://dx.doi.org/10.1016/j.ijpe.2007.02.046

Martínez-Lorente, A.R., \& Martínez-Costa, M. (2004). ISO 9000 and TQM: Substitutes or complementaries? An empirical study in industrial companies. International Journal of Quality \& Reliability Management, 21(3), 260-276. http://dx.doi.org/10.1108/02656710410522711

Matei, L., \& Lazar, C.G. (2011). Quality Management and the Reform of Public Administration in Several States in South-Eastern Europe. Comparative Analysis. Theoretical and Applied Economics, 4(4), 65-98.

McCrosson, S., Cano, M., O'Neill, E., \& Kobi, A. (2013). ISO9001 Certification in UK Organisations. A comparative study of motivations and impacts. Manuscrit auteur, publié dans QUALITA2013. Compiègne, France

Mersha, T. (2007). Narrowing ISO certification gap in Africa. International Journal of Productivity and Quality Management, 2(1), 65-80. http://dx.doi.org/10.1504/IJPQM.2007.011468

Meyer, J., \& Rowan, B. (1977). Institutionalized organizations: Formal structure as myth and ceremony. American Journal of Sociology, 83(2), 340-363. http://dx.doi.org/10.1086/226550

Neumayer, E., \& Perkins, R. (2005). Uneven Geographies of Organizational Practice: Explaining the Cross-National Transfer and Diffusion of ISO 9000. Economic Geography, 81(3), 237-259. http://dx.doi.org/10.1111/j.1944-8287.2005.tb00269.x

Okay, S., \& Semiz, S. (2010). The effects of ISO 9000 quality management system implementation in small and medium-sized textile enterprises: Turkish experience. African Journal of Business Management, 4(14), 2921-2933. 
Otsuki, T. (2011). Effect of ISO standards on exports of firms in Eastern Europe and Central Asia: An application of the control function approach. Osaka School of International Public Policy: Discussion paper.

Otzetova, A., \& Enimanev, K. (2012). Certification in Bulgaria-the case of courier companies. Scientific Works of the Ruse University, 51(5.1).

Palys, T. (2008). Purposive Sampling. In Lisa M. Given (Ed.) (2008). The Sage Encyclopedia of Qualitative Research Methods. Thousand Oaks, CA: Sage, 2, 697-698.

Pan, J. (2003). A comparative study on motivation for and experience with ISO 9000 and ISO 14000 certification among Far Eastern countries. Industrial Management \& Data Systems, 103(8), 564-578. http://dx.doi.org/10.1108/02635570310497611

Patton, M.Q. (2001). Qualitative Research and Evaluation Methods. 2nd Edition. Thousand Oaks, CA: Sage Publications.

Pecht, M., \& Boulton, W. (1995). Quality Assurance and Reliability in the Japanese Electronics Industry. In Howard, M. M. (2003), Electronic Manufacturing and Packaging in Japan, Chapt. 6, JTEC Panel Report. The weakness of civil society in post-communist Europe. Cambridge University Press.

Pivka, M \& Ursic, D (2002). The impact of ISO 9001 certification process on Slovenian companies. Journal for East European Management Studies, Hampp, Mering, 7(1), 27-45

Poksinska, B. (2010). When does ISO 9000 lead to improvements? International Journal of Productivity and Quality Management, 2(5), 124-136.

Poksinska, B., Dahlgaard, J., \& Antoni, M. (2002). The state of ISO 9001 certification: A study of Swedish organisations. The TQM Magazine, 14(5), 297-306.

http://dx.doi.org/10.1108/09544780210439734

Powell, W., \& DiMaggio, P. (1991). The New Institutionalism in Organizational Analysis. Chicago: University of Chicago Press.

Prajogo, D., \& Sohal, A. (2006). The Implementation of ISO 9000 in Australian Organisations: a comparison between the 1994 and the 2000 versions. Report on a study conducted by the Australian Supply Chain Management Research Unit, Monash University and supported by JAS-ANZ.

Ragothaman, S., \& Korte, L. (1999). The ISO 9000 international quality registration: An empirical analysis of implications for business firms. International Journal of Applied Quality Management, 2(1), 59-73. http://dx.doi.org/10.1016/S1096-4738(99)80004-9 
Rayner, P., \& Porter, L. (1991). BS5750/IS09000-The Experience of Small and Medium-sized Firms. International Journal of Quality \& Reliability Management, 8(6), 16-28.

http://dx.doi.org/10.1108/EUM0000000001639

Rosenkopf, L., \& Abrahamson, E. (1999). Modeling reputational and informational influences in threshold models of bandwagon innovation diffusion. Computational and Mathematical Organizational Theory, 5, 361-384. http://dx.doi.org/10.1023/A:1009620618662

Ruzevicius, J., Adomaitiene, J., \& Sirvidaite, J. (2004). Motivation and Efficiency of Quality Management Systems Implementation: A Study of Lithuanian Organizations. Total Quality Management, 15(2), 173-189. http://dx.doi.org/10.1080/1478336032000149018

Saleem, I., Siddique, I., Akmal, A., Masud Khan, M., Usman Khan, M., \& Sultan, S. (2011). Impact assessment of ISO 9000 series on the organizational performance: Empirical evidence from small and medium enterprise (SME) sector of Pakistan. African Journal of Business Management, 5(26), 10885-10892.

Sampaio, P., Saraiva, P., \& Guimarães Rodrigues, A. (2009). ISO 9001 certification research: Questions, answers and approaches. International Journal of Quality \& Reliability Management, 26(1), 38-58. http://dx.doi.org/10.1108/02656710910924161

Sampaio, P., Saraiva, P., \& Guimaraes Rodrigues, A. (2010). A classification model for prediction of certification motivations from the contents of ISO 9001 audit reports. Total Quality Management, 21(12), 1279-1298. http://dx.doi.org/10.1080/14783363.2010.529367

Santos, G., \& Millán, A. (2013). Motivation And Benefits Of Implementation And Certification According ISO 9001-The Portuguese Experience. International Journal for Quality Research, 7(1), 71-86.

Santos, G., Costa, B., \& Leal, A. (2014). Motivation and benefits of implementation and certification according ISO 9001: The Portuguese experience. International Journal of Engineering, Science and Technology, 6(5), 1-12. http://dx.doi.org/10.4314/ijest.v6i5.1

Scott, W. (1995). Institutions and organizations. Theories and research. London: Sage.

Shapiro, S. (1987). The social control of impersonal trust. American Journal of Sociology, 93, 623-658. http://dx.doi.org/10.1086/228791

Singels, J., Ruël, G., \& Van De Water, H. (2001). ISO 9000 series-Certification and performance. International Journal of Quality \& Reliability Management, 18(1), 62-75. http://dx.doi.org/10.1108/02656710110364477

Stiptzov, V. (2012). Why and how should we certify? Sofia, LTU. 
Sun, H. (2000). Total Quality Management, ISO 9000 Certification and Performance Improvement. International Journal of Quality \& Reliability Management, 17(2), 168-179. http://dx.doi.org/10.1108/02656710010304573

Taylor, W.A. (1995). Organizational differences in ISO 9000 implementation practices. International Journal of Quality \& Reliability Management, 12(7), 10-27. http://dx.doi.org/10.1108/02656719510093529

Terlaak, A., \& King, A. (2006). The effect of certification with the ISO 9000 Quality Management Standard: A signaling approach. Journal of Economic Behavior and Organization, 4, 579-602. http://dx.doi.org/10.1016/j.jebo.2004.09.012

Thilakarathne, P., \& Chithrangani, S. (2014). A study on analysis of managerial attitudes towards ISO9001: 2008 quality management system introduction and implementation process in Sri Lanka. International Journal of Economics, Finance and Management Sciences, 2(2), 123-131. http://dx.doi.org/10.11648/j.ijefm.20140202.12

Torre, P., Adenso-Diaz, B., \& González, B. (2001). Empirical evidence about managerial issues of ISO certification. The TQM Magazine, 13(5), 355-360.

http://dx.doi.org/10.1108/EUM0000000005861

Van der Wiele, T., Iwaarden, J., Williams, R., \& Dale, B. (2005). Perceptions about the ISO 9000 (2000) quality system standard revision and its value: The Dutch experience. International Journal of Quality \& Reliability Management, 22(2), 101-119.

http://dx.doi.org/10.1108/02656710510577189

Vasconcelos, I., \& Vasconcelos, F. (2003). IS09000, Consultants and Paradoxes: A Sociological Analysis of Quality Assurance and Human Resource Techniques. Revista de administraçion contemporanea, 7(1), 173-194. http://dx.doi.org/10.1590/S1415-65552003000100009

Vilkas, M., \& Vaitkevicius, S. (2013). Typological Models of Motives and Effects of Adoption of ISO 9000 Series Standards. Inzinerine Ekonomika-Engineering Economics, 24(4) 373-384. http://dx.doi.org/10.5755/j01.ee.24.4.4535

White, S. (1991). Gorbachev and After. Cambridge: Cambridge University Press.

Williams, J. (2004). The impact of motivating factors on implementation of ISO 9001:2000 registration process. Management Research News, 27(1/2), 74-84.

http://dx.doi.org/10.1108/01409170410784365

Withers, B., \& Ebrahimpour, M. (2000). Does ISO 9000 Affect the Dimensions of Quality Used for Competitive Advantage? European Management Journal, 18(4), 431-443. 
Xun Cao, X., \& Prakash, A. (2007). Diffusing Quality: Trade, FDI, \& The Cross-country Diffusion of ISO 9000 Quality Management Systems. Paper presented at University Seminar on Global Governance and Democracy. Duke University, 6 March.

Zaramdini, Z. (2007). An empirical study of the motives and benefits of ISO 9001 certification: the UAE experience. International Journal of Quality \& Reliability Management, 24(5), 214-234. http://dx.doi.org/10.1108/02656710710748358

Žeželj, S. (2013). The Implementation of a Quality Management System: A Case Study of Serbian Transport Organizations. International Journal for Traffic and Transport Engineering, 3(4), 397-407. http://dx.doi.org/10.7708/ijtte.2013.3(4).04

Journal of Industrial Engineering and Management, 2015 (www.jiem.org)

Article's contents are provided on a Attribution-Non Commercial 3.0 Creative commons license. Readers are allowed to copy, distribute and communicate article's contents, provided the author's and Journal of Industrial Engineering and Management's names are included. It must not be used for commercial purposes. To see the complete license contents, please visit http://creativecommons.org/licenses/by-nc/3.0/. 